\title{
Research on the Importance of Stylistic Work of Trade Union in College Campus Culture Construction
}

\author{
Qi haibang \\ Chongqing College of Electronic Engineering, Chongqing, China \\ 290610438@qq.com
}

Keywords: Importance, Stylistic Work, Trade Union, College Campus Culture Construction

\begin{abstract}
The relationship between trade union and campus culture in our country has an important relationship. It is of great value to study clearly the relationship between the two and play a certain role in reference to practical work and life. The work of college trade unions and the construction of campus culture all provide the foundation for strength and action support for the development of the school. The two are combined and work together to create a good work and study environment for all teachers and students and effectively promote the development of the school. The status of the school in society contributes to the education in our country. Studying thoroughly the relationship between trade unions and the construction of campus culture helps to clarify the position and function of colleges and universities in the construction of campus culture, enhances the influence function, effectively improves the execution power of trade unions in colleges and universities, further enhances the status of trade unions in colleges and universities and strengthens the construction of campus culture, Improving schooling levels will also exert some influence on the social environment. In response to the CPC Central Committee's decision on deepening the reform of the cultural system, it is necessary to promote the great prosperity and development of socialist culture.
\end{abstract}

\section{Introduction}

Nowadays, culture is of great significance to a country. It has increasingly become an important factor in the competition for comprehensive national strength. Our people are eager to see spiritual and cultural life be greatly enhanced. In his report to the 18th National Congress, Comrade Hu Jintao pointed out: "Culture is the national bloodline and the spiritual homeland of the people." To comprehensively build a well-to-do society and realize the great rejuvenation of the Chinese nation must promote the socialist culture develop prosperity, raise a new upsurge of socialist cultural construction, improve the country's cultural soft power, give play to the role of culture in leading the fashion, educating people, serving the community and promoting development "and" building a socialist strong nation, the key is to enhance the vitality of the entire national culture We should deepen the reform of the cultural system, liberate and develop the cultural productive forces, carry forward academic democracy and artistic democracy, and provide a broad cultural stage for the people. "(1) Colleges and universities, as important cultural origins and communication units, play an important role in cultural construction. Vigorously promote the construction of campus culture to cultivate a good school spirit, style of study, the full implementation of the party's education policy, create a good educational environment, improve the ideological and moral level of teachers and students, strengthen scientific and cultural literacy, for the daily work of the school and the progress of the campus Lay a good foundation.

\section{The Relationship between College Trade Union and Campus Culture Construction}

The composition of college union members is mainly the working class. Article 3 of the "Law of the People's Republic of China on Trade Unions" stipulates: "All manual workers and mental workers in enterprises, public institutions and agencies in China who derive their income from wages as their main source of income regardless of nationality, race, gender, occupation, Religious beliefs and educational attainment all have the right to participate in and organize trade unions in 
accordance with the law. "(2) Faculty and staff members are workers who derive their income from wage income. As part of the working class, their members, through their voluntary combination, form their own mass organizations. From the interests of representatives of trade unions in colleges and universities, trade unions in colleges and universities set up and exist according to the interests of faculty and staff members. It is an organization that reflects, represents and protects the interests of faculty and staff members. Whether representing and safeguarding the interests of staff and workers are to identify the class nature the important symbol.

The goal of the trade unions in colleges and universities is to rely wholeheartedly on teaching and doing their work, to carry out the party's all-encompassing reliance on the fundamental guidelines of the working class, to put in place the requirements of political assurance, system implementation, quality improvement and rights and interests protection We should mobilize the enthusiasm of all staff and workers in all aspects so that all talents, labor, knowledge and creativity will be respected and their vitality will burst forth. This will create a new situation in education and foster the builders and successors of the socialist cause.

The goal of the construction of campus culture is to establish the correct cultural values, to strengthen the cultural influence of staff and students, and promote the development of the school. With the development of the times, the culture is constantly changing. The tide of culture in society has an advanced positive aspect and a negative degenerative aspect. As an education base, colleges and universities need to absorb and filter the outside world culture, extract the cultural contents that fit the development of the school, integrate them into the task of campus culture construction, establish correct cultural values for teachers and students, and culture can naturally influence people in their atmosphere role, members of the school can be affected in their daily work and study life, invisible and school values tend to converge.

In their daily work, trade unions in colleges and universities safeguard the legitimate rights and interests of faculty and staff in accordance with the law, participate in various democratic management and supervision, participate in the formulation and implementation of the reform of the school program, coordinate labor relations and resolve labor disputes, and strengthen the education and training of highly qualified faculty and staff. The contents of campus culture construction mainly start from four levels, namely material culture construction, institutional culture construction, behavior culture construction and spiritual culture construction. In the process of unions work and campus culture construction in colleges and universities, the material and cultural construction of trade unions includes office space, faculty activities and venues for staff and workers. In order to enrich the work and study life of staff and workers, unions often purchase entertainment equipment, Fitness equipment, which intersect with the material and cultural construction of the campus. The cultural construction of the trade union system includes the system of teaching representatives and the working mechanism of trade unions, which are included in the construction of the institutional culture of the campus. The trade culture of the trade unions means that the staff and workers in the study, work and life the cultural connotation and cultural phenomena that are embodied in the kinds of behaviors and the main body of the behavior culture construction on the campus are teachers and students. Naturally, the two contents cross each other. On the spiritual and cultural construction level, the unions in colleges and universities carry out various activities Competition rich staff's spiritual and cultural life, in response to the main theme of the construction of campus culture, and its content are also interwoven.

Members of university trade unions generally hope that their own material and spiritual life will be able to be met and that their work can earn their income from work and be fair and just. Most of the faculty and staff members hope that the school will provide a good working environment and keep a pleasant mood into the vast educational undertaking. The legitimate rights and interests of the school itself can be guaranteed. After-class life is easy and healthy, rich and colorful. The trade unions must work hard to represent the wishes of their members. Faculty and staff also hope that the development of the school is getting better and better, the influence in the society is getting bigger and bigger, the status of education is increasing day by day, the quality of students trained is excellent and the country becomes a pillar. Campus culture emphasizes people-oriented, 
construction and development of the starting point lies in people. Campus culture construction project requires the participation of teachers and students in the school, the construction results will also affect all members of the school. Faculty and staff for the construction of the main campus culture, the role of culture in the process of making a trivial. The achievements in cultural construction are "taken from the people and used for the benefit of the people." All members of the school work together for cultural construction and enjoy common achievements in construction. The school itself has been continuously developed and steadily moved forward. This is also the concept of building a campus culture.

Colleges and universities unions fully play the role of a bridge in the work, closely linked with the faculty. The goal of trade unions in colleges and universities cannot be separated from the goal of building a campus culture. The construction of a campus culture cannot but consider the status quo of the trade unions. The two depend on each other and make progress together. The work of the trade unions revolves around the school's development goals, coordinating the interests of all parties, governing the campus in accordance with the law, promoting the construction of democratic politics and creating a good campus cultural environment so as to further strengthen the building of campus culture. The goal of the construction of campus culture also closely around the school's development goals, construction projects can rely on the work of trade unions in the smooth facilitation of the faculty to improve the speed and breadth of campus culture, but also can promote the school's work the smooth progress.

\section{The Development Countermeasure of College Union and Campus Culture Construction Integration}

Teachers are engineers of human souls. All faculty members in colleges and universities have the responsibility of educating people. And educators themselves must constantly receive education to update their ideology, scientific and cultural knowledge, and keep pace with the times to meet the requirements of the reform and development of colleges and universities. In the process of education, trade unions need to pay attention to individuality cannot be generalized, and adopt different education methods for different faculty members. The trade unions in colleges and universities should also emancipate their minds, update their concepts and establish the awareness of reform, competition, democracy, legal awareness, talent awareness, quality awareness and awareness of effectiveness, taking social responsibility and devoting themselves to academic prosperity, and taking the great cause of the Chinese nation Rejuvenation as our own responsibility, establish a new concept of cultivating the nation's nucleus, serving the social development, exploring social truths and leading the progress of civilization and making teachers guide and educate students with their moral pursuit, moral feelings, moral standards and moral image, Tireless, rigorous scholarship atmosphere.

The construction of the college representative conference system is of great significance, which plays an important role in the work of the college trade union and at the same time it can also affect the achievements of the campus culture construction. The construction of the congress system reflects the democracy and fully expresses the opinions and suggestions of the vast number of faculty members. Colleges and universities should fully understand the importance of strengthening the system of congress and strengthen the leading role of the faculty. In order to further improve the system of teaching representative assemblies, customer service formalism is required. In a considerable part of the schools, the system of teaching representative assemblies is a mere formality and does not really give play to its democratic significance. Trade unions also need to be well-acquainted and clearly accountable. At the same time, as a system of democracy, the system of the teaching representative assembly is also indispensable in safeguarding the policy provisions. The Provisional Regulations of the Faculty and Staff Representative Congress promulgated by the Ministry of Education and the China Education Union have played an important role in the establishment and development of the education representative assembly. However, with the continuous development of education in the world, the educational situation is constantly changing. The latest Regulations for Faculty Staff Delegates need to keep pace with the times, keep up with 
the trend of the times and ensure the timeliness of management. At the same time, schools should also collect and analyze members' opinions and suggestions according to their running conditions so as to formulate rules on the implementation of the regulations governing the development of their own congresses and implement them as school policy documents.

To strengthen the leadership ranks of unions in colleges and universities is an important part of building a contingent of cadres in colleges and universities. It is also the key to building a contingent of cadres in unions in colleges and universities. Only by building a contingent of leaders can we bring along an excellent union of trade unions and cadres in colleges and universities. The power of the leading ranks of trade unions in colleges and universities can effectively improve the working level of trade unions, lead the staff and workers in a better direction and promote the building of a campus culture. The leading ranks of trade unions in colleges and universities need to do a good job in two aspects. First, they should attach importance to organizational development. To set up a leading contingent of trade unions in colleges and universities, we must uphold the principle of managing cadres and the requirements of revolutionizing, rejuvenating, educating and professionalizing the party's cadres and continually improve the system of training, managing and selecting and appointing cadres so as to truly bring those ideas political quality is good, love union work, are willing to serve the masses of teachers and workers, cadres with the desire and ability to do a good job in college trade unions in the new period matching to the union job.

Different from Party work and administrative work, trade unions in colleges and universities have the characteristics and laws of mass work itself. Trade unions do not have the authority of party and government organs. Only by sending documents and notifying is not doing a good job. Unions need love and down-to-earth work style to attract staff and workers. We should adhere to the people-oriented principle, firmly root ourselves in the idea of serving the masses of teachers and workers and of serving the masses of teachers and staff wholeheartedly, and regard the faculty members' satisfaction or disapproval or approval as the standard and basis for testing the effectiveness of their work. We must persist in the work line of mass work that goes from the masses to the masses and often goes deep into the grassroots level to deepen the actual work. We should do a better job among the teaching staff and workers, effectively solve practical difficulties and specific problems, and solve problems for staff and workers. Under the new situation, the leading ranks of trade unions in colleges and universities should seriously consider how to safeguard the rights of faculty members to trade unions, how to safeguard the economic interests of teachers and staff and the political rights of being masters of their own affairs, and how to adapt themselves to the spiritual and cultural life of increasing faculty and staff demand. Trade unions in colleges and universities should achieve new breakthroughs in trade union work with new ideas, new standards and new requirements. To continuously promote the concept of innovation, institutional innovation, theoretical innovation, activities, innovative ways to achieve a bright spot, a characteristic, a first-class goal. According to the requirements of "developing new ideas, reforming new breakthroughs, opening up new prospects and opening up new work in all fields", we must strive to improve the ability to solve new problems and open up new prospects and realize the realization of the unions of colleges and universities in the new era Work breakthrough and development, and strive to open up a new road to trade union work.

\section{Conclusion}

It is of great value to study clearly the relationship between the trade union and the construction of campus culture, and can be used as a reference in practical work and life. The work of college trade unions and the construction of campus culture all provide the foundation for strength and action support for the development of the school. The two are combined and work together to create a good work and study environment for all teachers and students and effectively promote the development of the school. The status of the school in society contributes to the education in our country. Education can be a powerhouse. The construction and prosperity of our country cannot be separated without the numerous organizations and units in our society. If we can start with the smallest details and work hard, the power of solidarity must be strong. 


\section{References}

[1] Kong Haitang. On the cultural construction of trade unions in colleges [J]. Trade Unions Tribune (Journal of Shandong Institute of Trade Unions Management. 2013 (03)

[2] Zhu An. "Problem-driven active learning" in the life science classroom teaching application [J] Hua Zhang 2012 (32)

[3] Dong Junyi, Lu Qianchang. The role of unions in the construction of campus culture and strengthening measures [J]. People's Forum. 2012 (23)

[4] Xu Ning, Wei Shuangyuan University culture construction under the perspective of trade union [J]. Hua Zhang. 2012 (14)

[5] Sun Park, Chen Yao. To lead the university culture construction with the socialist core value system [J] .Research in Ideology, 2010 (10) 